\title{
Building a Simulation Model of the Currency Basket Peg System
}

\author{
Michiru Kunitomo *1 \\ Takashi Iba ${ }^{* 2}$ \\ Hideki Takayasu ${ }^{* 3}$ \\ *1 Graduate School of Media and Governance, Keio University \\ $*_{2}$ Faculty of Policy Management, Keio University \\ *3 Sony Computer Science Laboratories, Inc.
}

\begin{abstract}
This paper presents a institutional framework for the currency basket peg system. After the Asian currency crisis, the needs of seeking adaptive currency system has risen up but the best currency system has not still appeared. In this paper, we propose the model of "the currency basket peg system". This model realize the currency basket peg system on the computer. With using it, we investigate conditions that the currency basket peg system works.
\end{abstract}

Keywords: Currency Basket Peg System, Exchange Rate Regime, Complex Systems, MultiAgent-Based Model.

\section{Introduction}

This paper explores the adaptive currency regime which reduces the exchange risk. For the purpose, we propose "currency basket peg system model" and seek the possibility of the system as the alternative currency system. We examine under which conditions it works stably using multi-agent simulation.

The Asian currency crisis in 1997-1998 revealed the dependency of fixing exchange rate in East Asian economy to U.S. dollar. After the crisis, more and more distrusts to dollar peg currency system have risen up, and the needs for introducing unified currency in East Asia has been increasing. The basket peg currency system is considered as the system which will make a footing in this. However, there are many institutional restrictions to carry out the system and it has not set to practice applying the system into the actual world.

In this paper, we propose the currency basket peg system model which can be simulated on the computer. And we can study the fundamental conditions to build a foundation of the system.

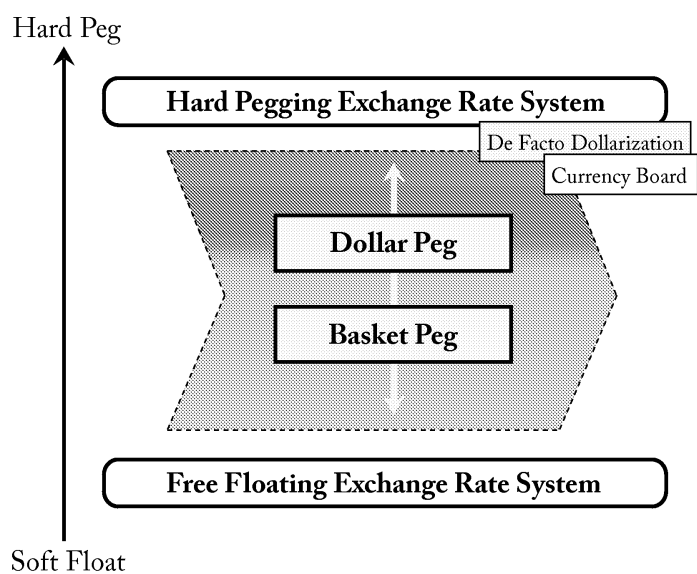

Figure 1: An overview of exchange rate systems

\section{Background}

\subsection{Needs for the alternative ex- change rate system}

We are going to begin at considering which currency system is superior to one another. The question which currency system would be effective is the general research issue under consideration. And it is hard to conclude this kind of issue to be right or wrong because there are many kinds of exchange rate systems and each system has advantages and disadvantages respectively.

In this situation, IMF offers an reference opinion. The opinion of IMF, which is called "two corner solutions", is that the desirable exchange rate system enduring through the currency crisis is either the free floating exchange rate system or the hard pegging exchange rate system [1] (Figure 1). However, there is another view of objecting to IMF's opinion. The working paper of the APEC Finance Ministers Meeting ${ }^{1}$ suggested the possi-

\footnotetext{
${ }^{1}$ The ASEAN Plus Three Finance Ministers Meeting held in May 2000, made the research group and their first
} 
bility of the system based on the basket peg as the alternative exchange rate system [2].

In addition, more and more researchers refer the importance of the middle level exchange system that is suitable for the regional economic structure. They, the middle-level oriented researchers, advocate the BBC system which is composed of "Basket", "Band", and "Crawl" [3]. This combination is considered as one of the promising mechanism.

After the Asian currency crisis, East Asia nations have been switching from focusing on U.S. economy to East Asian one. The reason of this is the Asian currency crisis demonstrated that East Asian Economy heavily depended on the United States. This retains a tie between the East Asia countries and makes the currency basket peg system important to the exchange rate system.

\subsection{Mechanism of the currency bas- ket peg system}

The currency basket peg system is defined as an exchange rate system that one country's currency is linked to the currency basket which can be got to average the multiple currency to volume weighted. Generally, the basic currencies that make up the currency basket are U.S. dollar, yen and euro. As the one way of partition, the currency weight is decided according to a total trade amount. This, however, has no scientific ground [4]. The validity of the way that the currency weight is decided by a total trade amount is totally restricted by the applied situation.

In this paper, the currency weight is originally defined by the multiple currency system (Takayasu model [4]). In Takayasu model, the traffic in the each currency on the basket peg currency system is figured up with each passing day and basket currency' weight is according to this rate (Figure 2 ). The total amount of each currency varies constantly. Therefore the weight of the basket peg currency fluctuates by the day.

\subsection{Advantages of the currency bas- ket peg system}

The currency basket peg system has some advantages. First of all, the system reduces exchange risks, for instance, the global exchange risk which is taken by a global company. Secondly, this system works as a stabilizer. More than one currency will participate in the basket and this contribution to keeping the regional economy well-balanced. Finally, the basket peg system will be effective against a sharp currency depreciation. When the

working report in March 2004.

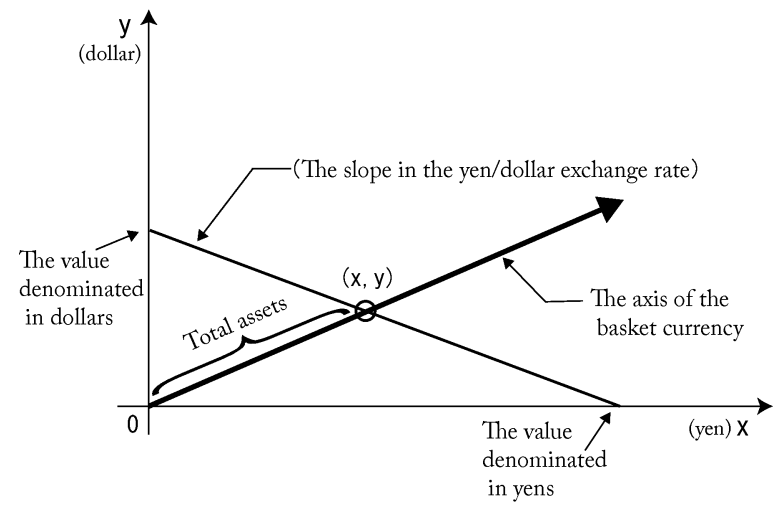

Figure 2: The axis of the basket currency [4]

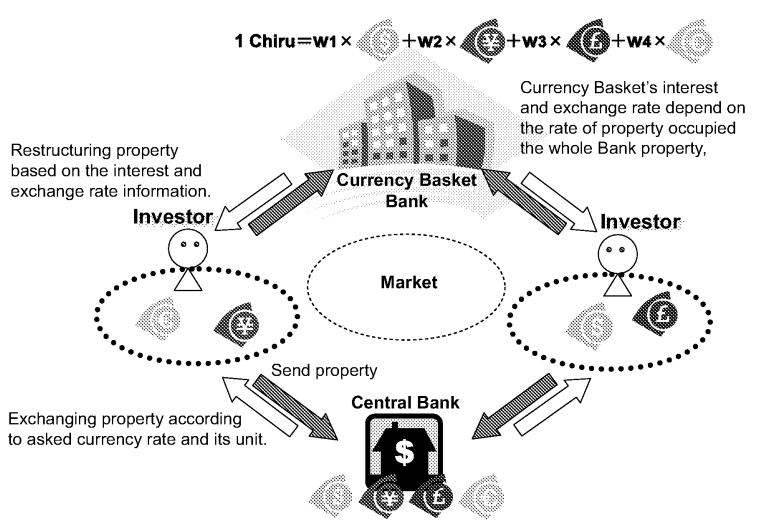

Figure 3: An overview of the currency basket peg system

collapse of the currency occurs, the currency basket peg system controls inflation or separates damages due to a sharp decline in currency.

\section{The Currency Basket Peg Model}

\subsection{An overview of the model}

We construct "the currency basket peg model" with using the Component Builder and PlatBox Simulator as tools for simulation [5]. This model is designed for analyzing the condition of the currency basket peg system.

There are ten currencies in our model; the U.S. dollar, yen, euro, yuan, won, Philippines peso, rupiah, baht, Singapore dollar, and Hong Kong dollar (Figure 4). The currency basket are composedd of these currencies.

Our model has four types of agents; Investors, Bank, Basket Currency Bank, and Market. Each of them have behavior, information, and relation to other agents (Figure 5, 6, 7). An Investor 


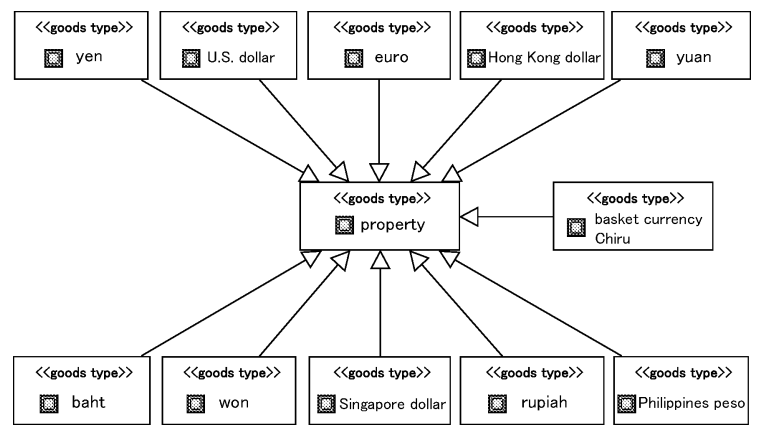

Figure 4: Class diagram of constitutive currencies in our model

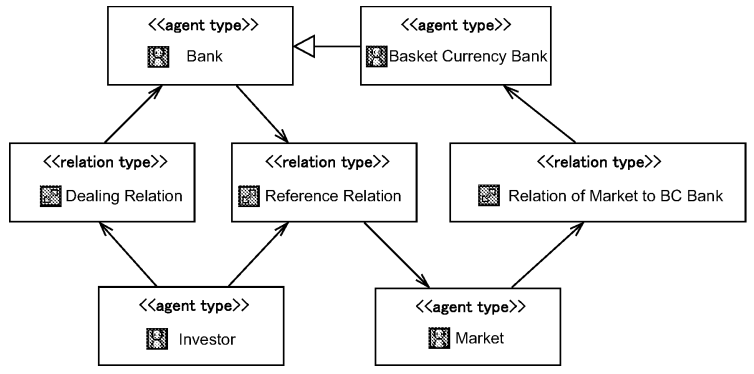

Figure 5: Class diagram of relations in our model

agent gets information about the interests and the exchange rate from the Market agent through the "Reference Relation" and deals with the correspondent Bank agent through the relation of "Dealing Relation" (Figure 7). Then Bank agent starts transaction while watching the market fluctuation. Investor agent has two types of information (Figure 7). One is "View Width", and another is "Preference Degree". "View Width" is the length to see interests and the exchange rate. And Preference Degree is the numeric indication of preference of the risk. Using this two types of Information, Investor agent does the "Properties Construction Behavior". In other words, Investor agent offer units of exchange and face amount to Bank/Basket Currency Bank agent and exchange properties.

\subsection{Flow of the simulation}

We overview the flow of the simulation along the time series. For the analysis, we assume following two situations.

- Situation 1: There is not a currency basket in the world.

- Situation 2: There is a currency basket in the world.

In the Situation 1, when the clock records the time, Market agent renews the information of interests and the exchange rate based on the ex-

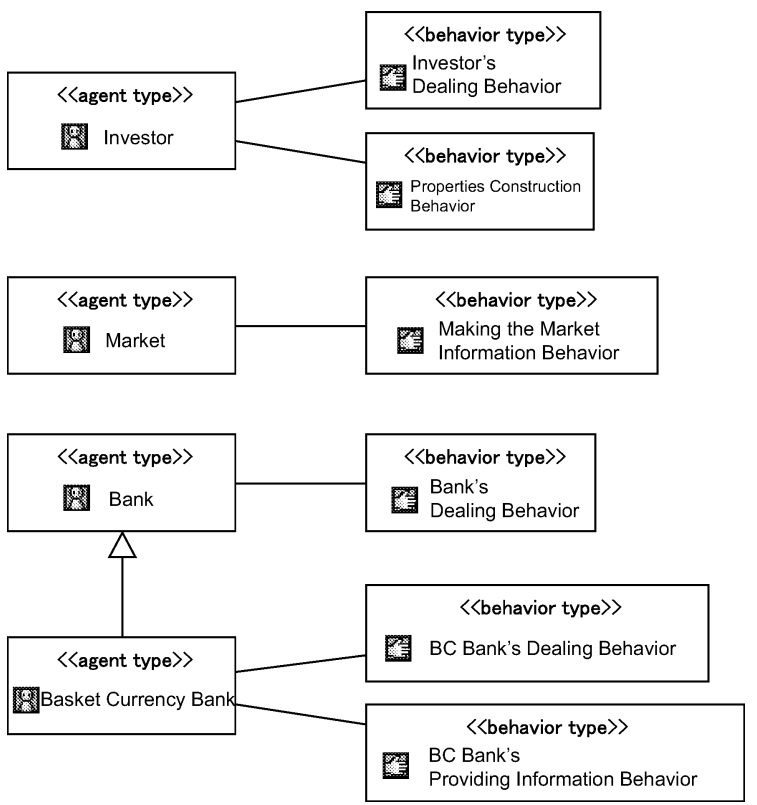

Figure 6: Class diagram of behaviors in our model

ternal data. After that, Market agent makes the "Market Information". Bank agent refers it and Investor agent refers "Market Information" offered by Bank agent. Relying on it, Investor agent decides the property distribution and sends "The face amount Information" and "Unit Information" of money. On the basis of this, Bank agent sends the amount to Investor agent.

On the other hand, in the Situation 2, after Market agent renews the information of interests and the exchange rate, Market agent inquires basket currency interests and the exchange rate of Basket Currency Bank agent. Then Basket Currency Bank agent calculates them on the rate of own property construction and sends the information to Market agent. Market agent adds the information about basket currency's interests and exchange rate to "Market Information". And when it's time, Basket Currency Bank agent, Bank agent, and Investor agent refer "Market Information" and Investor agent calculates its own property distribution to maximize it. Investor agent sends the information of "face amount information" and "unit information" to Bank/Basket Currency Bank agent. Each of them sends back the amount to Investor agent.

\section{Discussion}

\subsection{Model characteristics}

Our model has specific characteristics. First, our model incorporates Takayasu model that make the dynamic fluctuation of the interests and the 


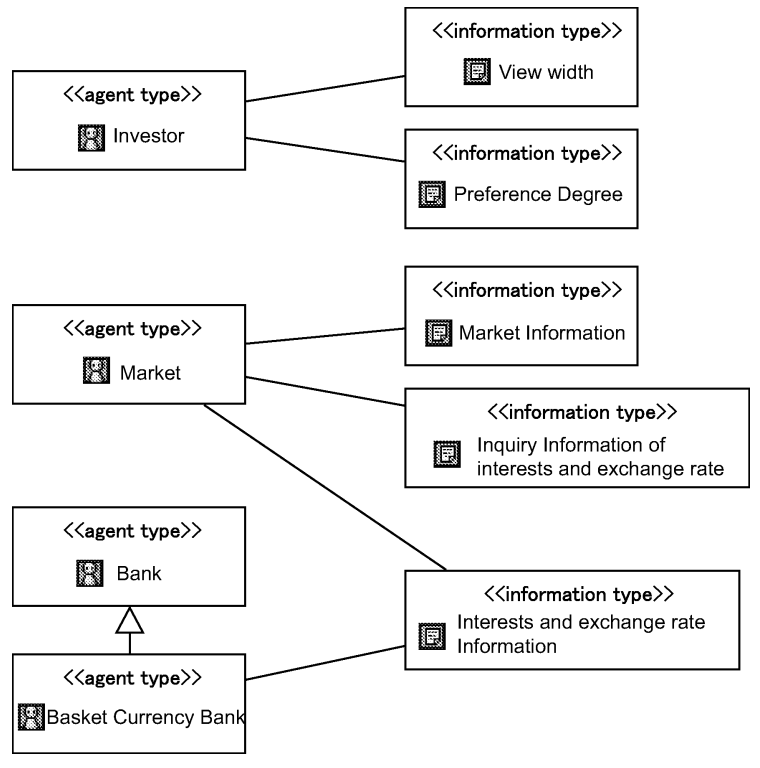

Figure 7: Class diagram of information in our model

exchange rate of the basket peg currency. Our model adopts the dynamic shifting weight based on the rate of the capital amount floating in a currency basket peg system, although each of currency' weight is typically fixed in the long span if it is composed of the basket.

Secondly, we build a unique institution of currency basket peg system in our model. Although the optimal weight is not acquired if the weight is decided on Market's natural fluctuation, we set Basket Currency Bank agent independently and this makes the system stable in our model.

Thirdly, Investor agent has several features about investment. Investor agent has got a long view scope or a short view one as the view width of past interests and exchange rate. Also Investor agent has another feature which is the risk preference degree of high or low. Combining these two features into one, there will be four patterns of investment features since these two initial features have two for each.

Finally, our model uses the past real data of interests and the exchange rate. This shows how the currency basket peg system would work on the Asian currency crisis.

\subsection{Comparison with the existing research}

Many researchers investigate the possibility of the basket peg system. The macro model of the basket peg system have been already proposed. One of them argue that the best exchange rate regime depends on the policy goal [6]. This kind of research dealing with the design of the market system in the light of the policy is macroscopic research.

As compared with this, our model applies the micro model of the basket peg system. We use the multi-agent-based model and examine the basket peg system in terms of the interaction of agents based on the idea of Complex System.

\section{Conclusion}

In this paper, we proposed a framework for making the currency basket peg system viable and examined an adaptive currency regime.

After the Asian currency crisis, various approaches have been considered for the cooperation of regional economy in the East Asia. However, because there still have been the deep economic disparity in the East Asia, the cooperation remains out of sight. Under that condition, it is effective to use the simulation with the past real data and to examine under what conditions the currency system works.

\section{References}

[1] Ogawa, E.: Tsuukakiki to Kokusai tsuukaseido kaikaku.(in Japanese), [The Currency Crisis and the Reformation of International Currency System], Hirashima, S.(Ed.); Gendai gaikokukawaseron.(in Japanese), [The Modern Foreign Exchange]. Yuhikaku Co.,Ltd. (2004)

[2] ASEAN plus 3 Research Group. and Institute for International Monetary Affairs (IIMA).: Toward a Regional Financial Architecture for East Asia. http://www.asean sec.org/16115.htm. , http://www.mof.go.jp/ jouhou/kokkin/ASEAN+3research.htm(2004)

[3] Wiliamson, J.: Exchange Rate Regimes for Emerging Markets: Reviving the Intermediate Option. Institute for International Economics (2000)

[4] Takayasu, H.: Keizaibutsurigaku no Hakken. (in Japanese), [Discovery of the Econophysics]. Kobunsha Co.,Ltd. (2004)

[5] Iba, T.: Understanding Social Complex Systems with PlatBox Simulator. The 5th International Conference on Computational Intelligence in Economics and Finance (2006)

[6] Yoshino, N. and Kaji, S. and Suzuki, A.: The basket-peg, dollar-peg, and floating: A comparative analysis. Journal of Japanese International. Economies 18 (2004) 183-217 